NBER WORKING PAPER SERIES

FINANCIAL DISTRESS IN THE GREAT DEPRESSION

\author{
John R. Graham \\ Sonali Hazarika \\ Krishnamoorthy Narasimhan \\ Working Paper 17388 \\ http://www.nber.org/papers/w17388 \\ NATIONAL BUREAU OF ECONOMIC RESEARCH \\ 1050 Massachusetts Avenue \\ Cambridge, MA 02138 \\ September 2011
}

We thank two anonymous referees, Michael Bradley, Alon Brav, Murillo Campello, Bill Christie (the editor), Harry DeAngelo, Laura Field, David Hsieh, Pete Kyle, Mike Lemmon, Antionette Schoar, Dennis Sheehan, Sheri Tice, Mike Weisbach, and seminar participants at Duke, Indiana University, Penn State, Tulane, and UCLA for valuable feedback. We acknowledge financial support from the Hartman Center at the Fuqua School of Business. Graham acknowledges financial support from an Alfred P. Sloan Foundation fellowship. Hazarika acknowledges financial support from PSC-CUNY and the Baruch College Fund. Any errors are ours alone. The views expressed herein are those of the authors and do not necessarily reflect the views of the National Bureau of Economic Research.

NBER working papers are circulated for discussion and comment purposes. They have not been peerreviewed or been subject to the review by the NBER Board of Directors that accompanies official NBER publications.

(C) 2011 by John R. Graham, Sonali Hazarika, and Krishnamoorthy Narasimhan. All rights reserved. Short sections of text, not to exceed two paragraphs, may be quoted without explicit permission provided that full credit, including $\odot$ notice, is given to the source. 
Financial Distress in the Great Depression

John R. Graham, Sonali Hazarika, and Krishnamoorthy Narasimhan

NBER Working Paper No. 17388

September 2011

JEL No. G0

\begin{abstract}
$\underline{\text { ABSTRACT }}$
We use firm-level data to study corporate performance during the Great Depression era for all industrial firms on the NYSE. Our goal is to identify the factors that contribute to business insolvency and valuation changes during the period 1928 to 1938 . We find that firms with more debt and lower bond ratings in 1928 became financially distressed more frequently during the Depression, consistent with the trade-off theory of leverage and the information production role of credit rating agencies. We also document for the first time that firms responded to tax incentives to use debt during the Depression era, but that the extra debt used in response to this tax-driven "debt bias" did not contribute significantly to the occurrence of distress. Finally, we conduct an out of sample test during the recent 2008-2009 Recession and find that higher leverage and lower bond ratings also increased the occurrence of financial distress during this period.
\end{abstract}

John R. Graham

Duke University

Fuqua School of Business

100 Fuqua Drive

Durham, NC 27708-0120

and NBER

john.graham@duke.edu

Sonali Hazarika

Baruch College/CUNY

Zicklin School Of Business

One Bernard Baruch Way

55 Lexington Avenue at East 24th

New York, NY 10010

sonali.hazarika@baruch.cuny.edu
Krishnamoorthy Narasimhan

PIMCO

840 Newport Center Drive

Newport Beach, CA

Krishna.Narasimhan@pimco.com 
Recent events have contributed to the belief that debt magnifies the negative effects of an economic downturn. Some argue that the bias in the tax system towards debt encourages companies to use excessive debt, and this exacerbates economic contractions. For example, Jason Furman, deputy director of President Obama's National Economic Council, told a congressional panel in 2009, "The (tax) disparity between debt and equity financing encourages corporations to finance themselves more heavily through borrowing. This leverage in turn increases the financial fragility of the economy, an effect we are seeing quite dramatically today." This view is also prevalent overseas. Adair Turner, chairman of Britain's uber-regulator, the Financial Services Authority, believes that there is too much debt in the financial system. "There is a huge bias in the tax system towards debt," Turner said, attributing this bias to the ability of companies to deduct interest payments before computing taxable profits. "If we can't change that, then the regulatory approach needs to lean against that." Numerous academic papers regress debt ratios on variables including a measure of the corporate marginal income tax rate (see Graham (2003) and IMF (2011) for reviews). While many of these papers document a positive elasticity of debt usage with respect to corporate income tax rates, none of the extant papers are designed to explicitly test for the effects of debt bias on corporate solvency.

To address debt bias and related issues, we study the effects of financial distress at the firm-level during the two worst financial calamities in the last hundred years, the Great Depression and the 2008-2009 Recession. That is, we examine the effect of debt on financial distress during time periods when it should matter the most, a severe economic downturn. Using logistic specifications that examine the extent to which having debt increases the probability of encountering distress, we find a significant, positive effect during the Depression era. However, our findings are not supportive of significant 
negative outcomes occurring due to debt bias. In a first stage analysis of debt bias effects, we quantify the amount of extra debt that firms use directly attributable to tax incentives, documenting a significant effect in the Depression (but none in the recent period). In a second stage, we do not find evidence that this extra tax-driven debt usage increases the probability of encountering financial distress.

Beyond studying the effects of taxes and debt bias, we more broadly examine the interplay between debt and financial distress. We begin by investigating whether firm characteristics had differential effects on corporate solvency and performance during the Depression. We examine firm-level data for all industrial firms on the NYSE from 1928 to 1938. To date, our paper is the most comprehensive firm-level examination of the causes of financial distress during the Depression era. Note that we do not attempt to identify corporate behaviors that caused or contributed to the Depression. Instead, we assume that the Depression occurred exogenously and use this environment to study corporate solvency and valuation during a stressful period, and in particular, the extent to which debt magnified the effects of the economic downturn on a given firm. We also conduct an 'out of sample' test using data from the recent 2008-2009 Recession time period.

The Depression caused significant economic, social and political turmoil and is arguably the most important economic event of the $20^{\text {th }}$ Century. Bernanke (1995) says, "To understand the Great Depression is the Holy Grail of macroeconomics." While 
macroeconomists have long studied the Depression, there is little firm-by-firm analysis of the era. $^{1}$

Studying corporations during the Great Depression contributes in several ways to our understanding of financial economics. First, understanding a severe economic shock like the Depression helps in anticipating and responding to a new crisis. While macroeconomists have developed several theories to explain the Depression, and there are several industry-level case studies (e.g., Bresnehan and Raff, 1991; 1992; Schiffman, 2003), ours is one of the few firm-level analyses. For example, Bernanke (1983) notes that the "pervasiveness of debtor insolvency" is a major aspect of the Depression that has not been studied adequately. We attempt to shed light on corporate insolvency during this era. While our analysis is at the level of the firm, it has implications at the macroeconomic level because, as Bernstein (1987; p. 50) notes, "it is decisions made at the microeconomic level of the firm that determine the overall performance of industries and indeed of the macroeconomy."

Second, there are several aspects of the Great Depression era that make it an ideal setting to study corporate performance. The Depression was generally a surprise, and therefore can to some degree be viewed as an exogenous shock to any particular

\footnotetext{
${ }^{1}$ Holderness, Kroszner, and Sheehan (1999) use the first SEC-mandated declaration of stock ownership to compare management stock positions in 1935 to those in 1995. Gordon $(1936,1938)$ examines the same SEC ownership data for a smaller set of firms. Hadlock and Lumer (1997) examine top management turnover for a sample of firms from 1933 to 1941. Ely and Waymire (1999) use firm level accounting data to examine the relation between intangible assets in 1927 and preDepression stock prices for some industrial firms. Christie and Nanda (1994) and Calomiris and Hubbard (1995) study the effects of the undistributed profits surcharge tax on dividend behavior in 1936 and 1937. Burch, Christie, and Nanda (2004) examine rights offerings during the 1930s and 1940s. Taussig and Baker (1925) use survey data to examine the corporation and its executives between 1904 and 1914. Recently, Graham, Hazarika and Narasimhan (2012) use firm-level data to examine the relation between board characteristics and corporate investment, debt usage, and firm value during the Depression years.
} 
company. ${ }^{2}$ Moreover, the Depression represents a prolonged period of disequilibrium. A severe negative economic environment can expose weaknesses in corporate form or operations that might be much harder to detect during normal or robust economic conditions, and the resulting cross-sectional variation in performance can enhance statistical identification of the key factors.

Third, examining the Depression helps solve, at least in part, the "peso problem" of economic research. The peso problem occurs in empirical analyses that do not include realizations of very severe negative events because these events occur only rarely. Studying the Depression provides information about the left tail of the distribution of possible outcomes, attenuating the peso problem. To the extent that results based on the Depression are consistent with those from research about the rest of the distribution, they reinforce our understanding of business performance in general. To the extent that results based on the left tail do not confirm results based on the rest of the distribution, they call into question the broad applicability of the previous results. Either way, analyzing the left tail provides (out-of-sample) insight to improve our overall understanding of financial economics.

Fourth, there are several aspects of our analyses that complement specific topics in the current literature. For example, while numerous papers argue that firms balance the marginal costs and benefits of debt financing when choosing their optimal amount of debt, the evidence explicitly documenting the costs of debt is somewhat sparse and narrow. For example, Warner (1977) examines the ex post costs of debt among 11 railroad companies and estimates that the ex post direct bankruptcy costs are about

\footnotetext{
${ }^{2}$ With hindsight, the seeds of the Depression can be detected in 1920 s macroeconomic data (Bernstein, 1987). Nonetheless, the Depression is generally considered to have been a surprise to most investors and corporations.
} 
5.3\% of firm value. Andrade and Kaplan (1998) examine the ex post costs of debt among 31 highly levered firms and find that when distress occurs the cost of financial distress is between 10 to 20 percent of firm value. Weiss (1990) studies 37 firms that declared bankruptcy in the early 1980s and estimates direct bankruptcy costs are $3.1 \%$ of firm value. Bris, Welch and Zhu (2006) estimate ex post legal costs for 212 firms filing for bankruptcy in New York and Arizona and find that direct Chapter 11 expenses average about $9.5 \%$ of asset value in their sample. Note that these are all ex post estimates (i.e., after distress has occurred) of the cost of debt. To the extent that they can be generalized, these papers indicate that the direct costs of debt are modest. By examining a much broader sample of firms, we gain a better understanding of the costs of distress (both financial and economic). ${ }^{3}$

Our results indicate that high leverage significantly increased the probability of becoming distressed during the Depression. In terms of whether firms use extra debt due to tax incentives ("debt bias"), ours is the first paper to regress debt ratios on a measure of tax rates to document that high tax rate firms used more debt during the Depression era. We use the estimated coefficients from this first stage regression to quantify the portion of debt usage attributable to tax incentives. We find a 3.7\% increase in the 1928 debt usage for firms with positive tax rates in 1927, compared to firms with tax rates of zero. We include this "extra debt used due to tax incentives" as an explanatory variable in the second stage but do not find significant evidence that this portion of debt usage increased the probability of distress. That is, we do not find evidence that debt bias contributed to the rate of corporate failure during the Depression.

\footnotetext{
${ }^{3}$ van Binsbergen, Graham, and Yang (2010) also study the cost of debt on a large sample but use very different samples and methodology. They estimate that at equilibrium levels, the all-in, ex ante cost of debt is about four percent of firm value.
} 
We also find that credit ratings were good predictors of leverage quality since firms with investment grade debt were significantly less likely to encounter distress. Furthermore, our conditional results vary in interesting ways. High leverage differentiates 'value' versus 'growth' firms. Specifically, among high 'value' firms (i.e., low M/B firms), the valuation of highly levered firms fell almost $40 \%$ more than for low leverage companies. In contrast, high versus low leverage led to less than a $6 \%$ incremental loss in valuation for 'growth' firms (i.e., high M/B firms).

It is important to interpret our results in light of possible endogeneity. For example, it is possible that increased debt usage is related to higher distress or to reverse causality (i.e., firms borrow more in response to the initial symptoms of distress). However, our analysis, examines whether firm characteristics in 1928 affect the probability of distress from 1930 to 1938 . Therefore, the timing of events makes it impossible for distress to occur first, unless distress started before 1928 but we do not detect it until the 1930s.

In some cases, it is also possible that the actions of corporations contribute to the occurrence of the Depression. Like Chevalier and Scharfstein (1996), Zingales (1998) and others, we argue that the nature of the event that we study makes this unlikely. An advantage of examining a largely unanticipated event (in both timing and severity), is that it is unlikely managers could anticipate the outcome of their actions or that the debt policy at a given firm contributed to the Depression. Therefore, the Depression can be thought of as an exogenous shock in terms of the effect of a given firm's choices on the probability of distress.

The rest of the paper is organized as follows. Section I provides background about the Great Depression. Section II develops our hypotheses. Section III describes the data and Section IV presents results about the probability that a firm encounters 
distress during the Depression, and the debt bias analysis. Section $\vee$ presents an 'out of sample' test using data from the recent 2008-2009 Recession time period. Section VI quantifies the value loss attributable to higher leverage during the Depression and Section VII concludes.

\section{The Great Depression}

The Great Depression followed a decade of progress and prosperity that many expected to continue. The Depression was a period of immense social and economic stress. In real terms, Gross National Product, declined from \$190.9 billion in 1928 to $\$ 141.5$ billion in 1933, the trough of the Depression. Unemployment increased from 4.2\% in 1928 to over 25\% in 1933. Following the trough there was an uneven recovery. Aggregate GNP did not reach 1928 levels again until 1938.

The stock market declined dramatically from 1929 to 1932 . The aggregate market value of common stock on the NYSE declined from about $\$ 60$ billion in December 1928 to about $\$ 20$ billion in December 1932. The Dow Jones Industrial Average (DJIA) lost four-fifths of its value between 1928 and 1932, declining from 300 in December 1928 to 59.93 in December 1932. Similarly, the Moody's Commodity Index, valued at 223.5 in December 1928, fell to 79.8 in December 1932. Trading volume on the NYSE dropped from 1.1 billion shares in 1929 to less than 500 million shares in 1932. Finally, broker loans, which totaled over $\$ 6.4$ billion in 1928, declined to about $\$ 430$ million by 1932 .

The Depression also led to a significant contraction in the corporate sector. Figure 1, Panel A shows that new corporate bond issuances fell sharply from 1929 to 1933 , and Panel B indicates that new equity issuances also fell significantly after 1929. Panel C shows that manufacturing production declined, while Panel D shows a significant increase in business failures from 1929 to 1932. Figure 2, Panel A shows that the 
percentage of firms with positive net income declined from about $61 \%$ in 1928 to about $18 \%$ in 1932; Panel B shows that the average nominal dividend per share declined from \$2.66 in 1929 to \$0.78 in 1933.

Panel C shows that by 1938 , about $25 \%$ of the firms in our sample became financially distressed (i.e., liquidation, restructuring with worthless stock, or declaring bankruptcy; the sample is described in Section III).

\section{Theory and Hypotheses}

In this section we develop hypotheses about factors that potentially contributed to corporate distress during the 1930s. Given the firm-level nature of our data, we focus on microeconomic and corporate finance explanations of distress; however, we also attempt to link to (and control for) phenomenon from the macroeconomic literature. We group these hypotheses by leverage, macroeconomic-related explanations, and several other factors.

\section{A. Leverage}

Numerous papers argue that a trade-off exists between the benefits and costs of debt. The benefits include interest tax deductions (e.g., Scott, 1976) and disciplining managers of low-growth firms with free cash flows by committing the firm to distribute the free cash flow as interest payments (Jensen, 1986). The tax benefits of debt were small during the Depression era because corporate tax rates were low (maximum ranged from $12 \%$ to $19 \%$ during the 1930 s). Therefore, other debt benefits such as monitoring and mitigating managerial entrenchment and agency problems (Berger, Ofek, and Yermack, 
1997) may have been relatively important. ${ }^{4}$ The costs of debt include underinvestment due to bypassing positive NPV investments (Myers, 1977) and costs of distress that occur when a firm cannot meet its fixed obligations.

Bernanke (1983) builds on the nearly forgotten debt-deflation theory of Fisher (1933) and states that outstanding corporate bonds and notes nearly doubled in the 1920s, which suggests that the effects of debt might be particularly noticeable during the 1930s. Bernanke (1995) develops an interesting hypothesis about the negative effects of debt during the Depression. During a deflationary period, the real obligation of fixed debt payments becomes larger in real terms. This "debt deflation" could be a neutral event for the overall economy if wealth is simply transferred from debtors to creditors. However, Bernanke points out that unexpected wealth redistribution away from debtors reduces collateral and therefore reduces the amount of capital that they can borrow, raising the possibility that debtors might have difficulty completing existing or initiating new positive NPV projects. Moreover, some firms would be forced to sell assets at depressed prices in order to cover debt payments, which might exacerbate the negative effects of debt at distressed firms (and also reinforce the downward spiral in prices).

Our first leverage null hypothesis is that the level of indebtedness does not affect the probability that a firm will encounter distress during the Depression. One alternative hypothesis is that debt provides monitoring, reduces entrenchment, and/or provides incentive to efficiently restructure operations when faced with a severe negative economic shock, and therefore reduces the likelihood or severity of distress. Another

\footnotetext{
${ }^{4}$ Safieddine and Titman (1999) provide evidence that among firms that are subject to takeover attempts that fail, the firms that increase their leverage the most act in the shareholders' interest after the termination of the takeover, and have the highest probability of remaining independent. The authors argue that leverage commits managers to make improvements that a potential raider would have made.
} 
alternative is that having more debt increases the likelihood and expected costs of distress. ${ }^{5}$ In a separate debt bias investigation, we also separately investigate whether the portion of debt usage tied to tax incentives leads to increased occurrence of distress.

Debt can interact with investment opportunities in interesting ways. Myers (1977) emphasizes that a troubled firm with a large amount of existing debt might not undertake projects with moderate but positive NPV because the benefits might accrue to existing bondholders, rather than to stockholders. This problem is heightened for 'growth' firms. It seems plausible that the effects of debt-deflation could also be heightened in 'growth' firms because they have fewer assets to sell if they are struggling to fulfill their fixed debt obligations. Our second leverage null hypothesis is that growth opportunities are unrelated to the costs or probability of encountering distress. The alternative hypothesis is that firms with growth opportunities suffer larger costs of debt and face higher probabilities of financial distress during the Depression.

Finally, we test whether rating agencies provided a useful service during the early part of the century. There is debate about the role of credit rating agencies and in particular whether they provide any information beyond the publicly available accounting and financial information about a firm. Our null hypothesis is that bond ratings provide no information beyond what is contained in publicly available information. Under the null, after controlling for firm characteristics, we expect that debt ratings will not be significantly related to the probability or severity of distress. Under the alternative that rating agencies provide useful information above and beyond that found in accounting information (e.g., information gathered in private conversations with company

\footnotetext{
${ }^{5}$ This would be consistent with the logic of some modern corporations that they use little debt because if a severe negative event were to occur, the firm would be faced with dire circumstances (Graham, 2000).
} 
presidents), we expect a negative relation between rating quality and the probability of distress.

\section{B. Macroeconomic Factors (Industry Composition)}

Several factors that can lead to corporate distress are closely linked to the macroeconomic literature. Bernstein (1987) argues that the Depression was severe and long-lasting because the U.S. economy was in the midst of a major transition at the time of the financial market meltdown. There was a growing middle class with increased tastes for consumer goods like refrigeration, canned foods, cigarettes, and automobiles with frills. At the same time, the old, heavy industries that had prospered for decades as the country expanded westward and built the infrastructure for automobile and rail travel began to slow. Ideally gains from the new consumer goods industries would grow sufficiently (in production and employment) to offset declines in heavy industries. In the 1930s, however, the nondurable and consumer goods industries were in their infancy. Any increase in employment or production that these industries experienced during the 1930s was not sufficient to overcome severe problems in the heavy, durable industries.

To test the Bernstein (1987) hypothesis that the slowdown was mainly confined to the old industries and that there was a transition towards newer consumer industries, we include a dummy variable that takes the value 0 if a firm manufactured consumer nondurable goods and 1 otherwise. The null hypothesis is that there is no significant difference in the probabilities of distress among 'old' and 'new' industries. The alternate hypothesis is that firms that produced durables are more likely to become distressed. ${ }^{6}$

\footnotetext{
${ }^{6}$ In modern research, Campello and Fluck (2006) also argue that consumers of durable goods face high switching costs and therefore durable goods industries suffer during a downturn.
} 


\section{Age}

Jovanovic and Rousseau (2000) study how technological change affects the economy and the aggregate stock market. They find significant 'vintage effects' in stock prices that are especially strong in the 1920s, which they interpret as indicating that firms that formed during the 1920 s performed better than firms that were formed during other decades. They argue that this occurred because there were numerous innovations during the 'Roaring 20s' that favored firms of that decade in terms of new technology, management techniques and manufacturing methods, which might have allowed 1920s entrants to be relatively well suited to handle the 1930s. Moreover, young firms in the 1920s were more likely to produce nondurable goods, and as argued in the previous section, they might have fared better during the Depression. In contrast, the 'liability of newness' hypothesis of Stinchcombe (1965) argues that younger firms are more prone to becoming distressed than older, more mature and better established firms. One of our specifications therefore includes a variable to determine the effect of firm age on the probability of distress during the Depression.

\section{Liquidity}

Hunter (1982) finds that the largest firms were able to accumulate liquid assets (i.e., cash and government securities) during the 1930s, even in the face of declining revenues, while small firms were unable to increase liquidity. Hunter argues that extra liquidity helped firms survive during the 1930s, when credit was hard to acquire. The null hypothesis is that liquidity does not affect the probability of financial distress. The alternative hypothesis is that illiquid firms have a higher probability of encountering distress. 


\section{E. Size, Profitability, Investments, and Volatility}

We control for firm size, in part because Bernanke (1983) summarizes research indicating that small firms were less profitable and encountered distress more often than large firms during the 1930s. Moreover, if the stock market can anticipate distress and discount equity prices accordingly, we expect negative returns to be a good predictor of future distress. Shumway (2001) finds this variable to be a significant predictor of bankruptcy during the 1980s. Thus, we expect to find a negative relation between firm size and the occurrence of distress.

We expect that firms with higher operating profits in 1928 will have lower probabilities of distress if their profitability enables them to withstand negative economic shocks. Thus, we expect a negative relation between operating profit and the probability and severity of distress. We also control for investment of the firm. Finally, we expect that firms with volatile cash flows will be more likely to encounter distress.

\section{Data and Variable Definitions}

\section{A. Data}

We hand collect a panel of firm-level data for all nonfinancial NYSE companies using CRSP between 1926 and 1938. We focus initially on the 657 industrial firms that existed in 1928. Of these, 34 firms are classified as utilities, 68 as railroads, and 34 as finance firms. After deleting these firms from the sample, we are left with 521 industrial firms. We also require that the firm be listed as of January 1928 , and that the firm not be delisted/distressed until at least December 1929. We exclude firms that were delisted before December 1929 because it is possible that these firms were already distressed prior to the inception of the Depression. This screen reduces our final sample to 443 industrial companies. 
We collect accounting data from Moody's Investment Manual for Industrial Securities. Moody's provides a brief history of the firm, the balance sheet, the profit and loss statement, the credit ratings for the firm's securities, and other general information.

We use several data sources to identify firms that became financially distressed. The first source is the Capital Changes Reporter, which lists the changes in the capital of a firm from the date of incorporation until dissolution. If a firm files for bankruptcy, liquidates, or undertakes a court-ordered reorganization or recapitalization, the information is available in the Capital Changes Reporter, along with the date of occurrence. The database also provides a stock price on the date that the significant capital change took place. Further, the database classifies common equity as 'worthless' when there are no buyers for the stock. In the event of a merger, the database also lists whether the merger was part of a reorganization. Moody's Manual provides a second source for identifying whether and when a firm becomes distressed. Moody's provides detailed reports of events including default, bankruptcy, liquidation, and reorganization. Finally, we use CRSP delisting codes to identify firms that delisted due to liquidation. Thus, we use three different sources to identify distressed firms, and in a majority of cases, the occurrence of distress is indicated in more than one source. However, we only require that a firm be identified as distressed in one source to be classified as distressed in our analysis. (The results reported below are robust to requiring that distress be identified in at least two of the three sources.)

We search the above databases for any indication of distress during the period January 1930 to December 1938. (In some analysis, we end the sample in December 1933.) We classify a firm as being distressed if at least one of the following occurs: the firm files for bankruptcy, liquidates, undertakes a court-ordered reorganization, 
recapitalizes when its shares are classified as 'worthless,' or is taken over as a result of one or more of the above problems.

We perform logistic regressions using DISTRESS as the dependent variable, where DISTRESS is a binary variable. DISTRESS equals one if the firm becomes financially distressed at any point during the Depression (i.e., during 1930 to 1938) and

equals zero otherwise. Additionally, to reduce noise, we winsorize all variables at the $5^{\text {th }}$ and $95^{\text {th }}$ percentiles.

For the 2008-2009 Recession we identify bankrupt firms from the UCLA-LoPucki Bankruptcy Research Database (BRD). We restrict our sample to public firms with $\$ 100$ million or more of total assets (measured in 1980 dollars). We also use CRSP delisting codes to identify firms that delist due to liquidation. We again delete utilities, banking, and financial firms. This screen reduces our final sample to 3,394 companies. In addition, we winsorize our variables at the $5^{\text {th }}$ and $95^{\text {th }}$ percentiles. DISTRESS equals one if the firm becomes financially distressed at any point between January 2008 and June 2011 (i.e., we consider the occurrence of distress beyond the official end of the recession) and equals zero otherwise.

\section{B. Variable Definitions}

The remainder of this section defines the explanatory variables. The market to book ratio is defined as the ratio of the market value of the firm's equity to book equity and is used to measure growth opportunities. Tobin's $q$, defined as the ratio of the market value of the firm's assets to book assets, is used to measure market valuation. We also include the standard deviation of the firm's monthly stock price during the year as a proxy for cash flow volatility.

Operating profit measures return on assets and is defined as earnings before 
interest and tax (EBIT) divided by total assets. Note that EBIT is not directly affected by the level of indebtedness of the firm. Size, as in Shumway's (2001) analysis of the probability of distress, is measured as the log transformation of the market capitalization of the firm in a given year, divided by total market capitalization of all CRSP firms in that year. As a robustness check, we also use the log of total book assets as a measure of firm size and generally find similar results. We measure leverage as the fraction of total debt to book value of assets. Total debt includes all forms of debt on the liability side of the balance sheet. We use book leverage rather than market leverage (i.e., book debt divided by the market value of the firm) because of the enormous fluctuations in market equity values during the 1930s.

We use the bond rating assigned by Moody's Investment Service for the year 1928 as a measure of a firm's ability to service its debt and its overall quality. We assign a value of 9 for a AAA rating, 8 for AA, 7 for $A, 6$ for $\mathrm{BBB}, 5$ for $\mathrm{BB}, 4$ for $\mathrm{B}, 3$ for $\mathrm{CCC}, 2$ for $\mathrm{CC}$, and a 1 for a $\mathrm{C}$ rating (the lowest 1928 rating for our sample firms). In the late 1920s, Moody's was more likely to provide a rating for common and preferred stock than it was for debt. In fact, we find a common stock rating for nearly every firm in our sample but a debt rating for only about half of the firms (primarily the firms that had debt in 1928). For the companies that had both debt and common stock ratings, in almost every case bonds were rated two levels higher than common stock, and preferred stock was generally rated between common equity and debt. For firms with unrated debt in 1928 , we assign a bond rating that is two levels higher than the common stock rating (e.g., we assign a rating of 7 to unrated debt if the common stock is rated 5 by Moody's). We use the log of the rating in our analysis, which imposes a nonlinear effect of improved ratings. As a robustness check, we repeat the analysis using the numerical value of the rating, rather than its logarithm and obtain similar results. 
We include capital investment and liquidity as control variables. Investment is calculated as the difference in gross fixed assets between the beginning and the end of the year divided by the total assets at the beginning of the year. We measure liquidity as the ratio of the firm's cash, inventory, and receivables to total assets, which we call current assets in the tables. The results do not change if we measure liquidity as cash only.

Age is the number of years since the firm was initially formed (as listed in Commerce Clearing House. Note that this date often predates the year of incorporation, as reported in Moody's). In an attempt to control for macroeconomic factors, we include a variable DUR, which takes on the value 1 if the firm produces 'old economy' heavy, durable products (one-digit SIC codes 1, 3, and 4).

\section{Summary Statistics}

Table I, Panel A provides summary statistics for 1928. The mean (median) operating profit for 1928 was 9.1\% (7.9\%) of total assets. (Though not reported in the table, this is a moderate improvement over the 1927 profits of $7.8 \%(6.9 \%))$. The mean (median) debt ratio of $11.7 \%(6.9 \%)$ is lower than the debt ratios of prior years. There is a wide dispersion in age, with the oldest firm in the sample being 168 years old, and the youngest firm being just one year old in 1928. The median debt rating is 6 (BBB) in 1928. Panel B provides pair-wise correlations for the variables.

Table II provides summary statistics for some key years and for the entire sample period from 1926 to 1938 . We can see that that median profitability, which was about $8 \%$ in 1928 , dropped to $-1 \%$ by 1932 . The recovery started in 1933 , when profitability rose to 2\%. Profits increased to $4 \%$ in 1938 . Similarly, book leverage dropped from a mean of $12 \%$ in 1928 to $10 \%$ in 1932 , and even further to $8 \%$ in 1938 . Median nominal assets 
declined from $\$ 24.4$ million in 1928 to $\$ 20.3$ million in 1933, after which assets increased modestly to $\$ 21.9$ million in 1938 . Asset size varies widely for the firms in our sample. The smallest firm had total assets of $\$ 395,000$, while the largest firm (U.S. Steel) had total assets of $\$ 2.4$ billion (in 1928 dollars).

\section{What Caused Corporate Distress During the Depression?}

\section{A. Logistic Regressions}

We estimate logistic regressions to determine whether pre-Depression firm characteristics predict distress during the Depression. To accomplish this, we estimate a model using data from 1928 to define the explanatory variables. The values of the explanatory variables should therefore not be endogenously affected by the onset of the Depression in 1929.

Table III presents the results of the logistic regressions estimating the probability of distress during the Depression. In Panel A, we track the sample of firms until the end of 1938 to determine whether a firm becomes distressed at any point during this period. We examine 1938 because, although the Depression bottomed out in 1932/1933, the economy did not reach its 1928 level again until a decade later. In Panel B, we base the distress variable on whether a firm became distressed by the end of 1933 .

In both Panels $A$ and $B$, the estimated coefficients for many of the variables have the expected sign, though not all are significant. We find that pre-Depression leverage is a positive and significant predictor of a firm experiencing distress during the 1930 s. $^{7}$ This is consistent with the fixed obligation of debt payments constraining corporate activity

\footnotetext{
${ }^{7}$ This result holds when the debt variable is measured net of the mean debt for a given firm's 2-digit SIC code industry.
} 
during the Depression and leading to distress. ${ }^{8}$ The debt coefficient is not consistent with pre-Depression monitoring by debtholders leading to improved performance during the economic crisis. This result is consistent with the implications of Opler and Titman (1994) that the overall effect of leverage on shareholder wealth is negative during a period of economic distress.

In terms of economic significance, for the mean firm, an increase in leverage by one standard deviation (from a debt ratio of $11.10 \%$ to a debt ratio of $23.38 \%$ ) increases the probability of distress by $58.05 \%$ (from $14.54 \%$ to $22.98 \%$, based on coefficients in Panel A, column (3)). This large increase in the probability of distress provides strong evidence that debt can be costly during a negative economic shock. We further quantify the cost of debt in Section VI.

The estimated coefficient on the debt rating is negative; therefore, credit ratings are significant predictors of distress during the Depression. As a robustness check we repeat the analysis using the linear rating variable, rather than the log of the ratings, and find similar results. Also, the result holds for both Panels A and B, and indicates that debt ratings provide information beyond that contained in the other variables included in the regression. ${ }^{9}$ The pre-Depression median credit rating of 6 (BBB) indicates that most firms were considered investment grade. For the mean firm in Panel A, an increase in rating by one notch (e.g., an increase from BBB to A) decreases the probability of distress by $36.45 \%$ (from $12.73 \%$ to $8.09 \%$ ).

\footnotetext{
${ }^{8}$ In a specification not shown in the table, the estimated coefficient on a variable that separately identifies bank debt (i.e., bank debt explicitly listed in the balance sheet or debt not rated by Moody's) is negative and insignificant.

${ }^{9}$ In unreported analysis, the credit rating variable is still a significant predictor of distress when fixed assets divided by total assets (which is itself significant) and interest coverage (which is itself not significant) are added to the specification.
} 
The coefficient on the durable goods indicator is insignificant in both Panels $A$ and B. In unreported analysis we replace the durable goods indicator with industry dummies, and these coefficients are also statistically insignificant. Thus, it appears that there were not significant differences in probabilities of distress between consumer durable and nondurable industries during the Depression. Furthermore, we find that with rare exception, operating profit, size, investment and age do not help explain the likelihood of financial distress. Thus, the explanatory power is driven by leverage and bond ratings alone.

In unreported analysis we include dummy variables for 49 industries defined by Fama and French (1997) but only two dummies are significant (and even then, only in some specifications) at the 10 percent level. However, including them does not significantly affect the coefficients for the other variables, so we drop the industry dummies in the reported analysis.

\section{B. Debt Bias Analysis}

We also investigate the potential effects of debt bias. In Table IV, we first identify the portion of debt usage attributable to tax incentives. To do so, we construct a marginal tax rate (MTR) dummy variable which is equal to one if a firm had positive tax liabilities in 1927 , i.e., if the firm had taxable income greater than $\$ 2000$ in 1927, and zero otherwise. During the Depression there was no tax-loss carryback provision in the tax code, and the tax-loss carryforward period was only two years; in this setting, a binary variable based on the existence of current-period tax liabilities is a reasonable measure of current-period tax status (though it is an ex post measure and therefore does not capture the ex-ante probability of being taxable).

Next, we estimate a regression with the dependent variable equal to the change in debt for the year 1928, normalized by total assets. The key explanatory variable is the 
MTR dummy variable, and control variables include M/B, profitability, firm size, tangibility and liquidity. The coefficient on the MTR dummy variable is significantly positive, indicating that debt usage increased in response to tax incentives. Firms with positive tax rates in 1927 increased their 1928 debt usage by $3.7 \%$ compared to firms with tax rates of zero. As a robustness check, we also define the MTR variable as the actual tax payments paid by a given firm, normalized by EBIT if taxable income is positive, and zero otherwise. The estimated coefficient remains significantly positive.

To our knowledge, these are the first results documenting tax incentives for using debt in the Depression era. (Our evidence provides an explicit tax interpretation to the evidence in footnote 8 of Calomiris and Hubbard (1995), who argue that only a small number of firms qualified to participate in the bond market, and that these firms issued the vast majority of the bonds.)

The fitted value from the tax variable in the first-stage regression is then used as an instrument for leverage in a second-stage probability of distress regression similar to Table III. The coefficient on the instrument is insignificant. Thus, we do not find significant evidence that the portion of debt usage attributable to tax incentives increased the probability of distress during the Depression. That is, we do not find evidence that debt bias exacerbated the negative consequences of the Depression. We acknowledge that measurement error in our second stage tax variable could reduce our power to detect debt bias.

In the 2008-2009 Recession era, the tax variable is not significant in the first stage regression (not reported in table). Therefore, this too fails to provide support for the debt bias hypothesis (in this case, we do not even find evidence that taxes affect debt choice in the first place). We again acknowledge that lack of power or noisiness in the tax variable can also lead to lack of significance in tests like these. In the next section we 
elaborate on our 2008-2009 Recession examination of the effects of debt and credit ratings on the occurrence of financial distress.

\section{Corporate Distress during the 2008-2009 Recession}

In this section we perform an out-of-sample-test of the causes of financial distress using data from the recent 2008-2009 Recession. Similar to Table III, we perform logistic regressions to determine which pre-Recession variables predict distress during the 20082009 Recession. We estimate the model using data from 2006 to define the explanatory variables. Since it was the last full year before the onset of the 2008-2009 Recession which officially began in December 2007 (source: National Bureau of Economic Research). We track the sample of firms until June 2011 to determine whether a given firm becomes distressed at any point during the years 2008 to June 2011. The results are presented in Table V. Similar to Table III, in column (1) of Table V we find that preRecession leverage is a positive and highly significant predictor of distress between January 2008 and June 2011. Further, in column (2) of Table V, we find that preRecession credit rating is negatively related to the probability of a firm experiencing distress during 2008 to June 2011. In column (3), we include both leverage and credit rating in the regression and find that leverage and pre-Recession credit rating continue to predict distress during the 2008-2009 Recession. In terms of economic significance, for the mean firm, a one standard deviation increase in leverage (from a debt ratio of $24.23 \%$ to a debt ratio of $44.05 \%$ ) increases the probability of distress by 31 basis points (from $0.45 \%$ to $0.76 \%$, based on coefficients in column (3)). Further, an increase in rating by one notch (e.g. an increase from BB to BBB) decreases the probability of distress by 38 basis points (from $0.67 \%$ to $0.29 \%$ ). 


\section{Value Loss during the Great Depression}

In this section we analyze firm valuation during the Depression. Relative to modern research, this analysis also provides "out of sample" estimates of some important quantities. For example, we estimate the value loss associated with having debt. Warner (1977), Weiss (1990), and Andrade and Kaplan (1998) estimate costs of distress for specialized and/or small samples. Our sample is much larger: we estimate the ex post cost of having debt for all industrial firms on the NYSE. Our sample permits an analysis of the costs of debt should an extremely negative economic event occur.

We sort the firms into portfolios based on 1928 leverage ratios and 1928 market to book ratios. Sorting creates unconditional quartiles of debt and unconditional quartiles of $M / B$, yielding sixteen portfolios. For each of these portfolios we report the cumulative change in average valuation (measured with Tobin's q) of the highest leverage portfolio and the lowest leverage portfolio. We then calculate the difference in cumulative market valuation between these two portfolios over time to determine the impact of leverage on firm valuation during the Depression.

In Table VI we present the difference in the cumulative change in valuation between the lowest leverage portfolio and the highest leverage portfolio. Figure 3 shows the cumulative change in market valuations for the lowest and highest leverage portfolios in each of the four market to book quartiles.

Figure 3 and Table VI indicate that leverage had noticeable effects only on low M/B firms. For high M/B firms (shown in the bottom two panels of Figure 3), market valuation fell considerably by 1932 , and in the case of the highest M/B firms, never fully recovered. This holds for both high and low debt firms. In contrast, for low M/B 'value' firms (the top two panels), market valuation fell through the early 1930s, regardless of the amount of debt. However, low-leverage value firms recovered much more rapidly 
than high-leverage value firms in the second half of the Depression. By 1938, the difference in valuations due to leverage was more than $40 \%$ for the portfolios in the lowest market to book quartile, and more than 30\% for the next lowest market to book quartile. $^{10}$

If we interpret market to book as a measure of growth options, then finding a significant negative effect of leverage for 'value' (i.e. low M/B firms), but not for 'growth' (i.e. high $M / B$ ) firms, is somewhat surprising because it is often argued that 'growth' firms are more susceptible to debt-induced value loss. For example, Myers (1977) argues that shareholders might not exercise positive NPV growth options in firms that already have substantial debt because the benefit of the new project might accrue to existing debtholders. At least for our sample, we do not detect this effect. It is of course true that there may not have been many positive NPV projects during the Depression, nor funds to pursue positive NPV projects, so this might not be the ideal environment to test Myers' hypothesis. Instead, our results indicate that 'value' firms recovered reasonably well during the Depression, and more so for 'value' firms with less debt. This is consistent with debt burden limiting the recovery of high-debt 'value' firms, relative to low debt firms during the Depression. In contrast, 'growth' firms did not recover during the Depression, independent of the presence of debt.

\section{Conclusion}

The Great Depression is one of the most important economic events of the twentieth century. This paper presents the first large-scale microeconomic analysis of

\footnotetext{
${ }^{10}$ To ensure that our results are not driven by industry effects, we conduct a similar analysis using only manufacturing firms. We find very similar results for manufacturing firms. Moreover, the results are confirmed in a multivariate regression that controls for profitability, size, and age.
} 
corporate performance and survival during this era. Firm-level data are used to investigate how characteristics like leverage, size, profitability, age, and investment affect corporate solvency during the Depression.

Our results indicate that highly levered firms and firms with low bond ratings had a high probability of becoming financially distressed during the Depression. We find similar results for the 2008-2009 Recession. Thus, we find results consistent with the trade-off theory. Our findings do not provide support for a bonding theory in which debt would have committed managers to manage their firms more efficiently and reduce the likelihood of encountering financial distress. We also find support for the information production role of credit rating agencies, indicating that agencies provide information above and beyond the publicly available variables included in our specification.

Further, we find that during the Depression, the consequence of higher leverage was particularly significant for 'value' firms. 'Value' firms with low leverage recovered sooner than their more highly levered counterparts. High-leverage 'value' firms lost almost half of their value, relative to low-leverage 'value' firms. An important caveat is that our measure of growth options (market-to-book) may proxy for things other than 'growth' versus 'value', and our results are confined to a historically rare event. Having said that, interpreted literally our results imply that policies that restrict debt usage in an effort to preserve fragile corporate investment opportunities may not achieve the desired outcome.

Finally, there has been considerable discussion of whether debt interest deductibility increases corporate debt usage to the extent that it exacerbates economic downturns. While our investigation into this topic is limited, we document that firms used debt in response to tax incentives in the Depression era. However, our results do not find any evidence to corroborate debt bias fears. In particular, we do not find evidence that 
the additional debt usage attributable to tax effects increased the probability of a firm experiencing financial distress during the Great Depression. We conjecture that firms with large, positive tax rates (that therefore have ample incentive to respond to debt tax incentives) are also stable and profitable. Therefore, either this profitability effect may more than offset any effects of debt bias, or perhaps the positive benefit of principal infusion that comes from debt issuance is the dominant effect of tax-induced debt usage. Due to possible lack of power, one should be careful not to over-interpret our findings. However, it is worth highlighting that to the extent that our finding of no increase in the occurrence of financial distress due to debt bias holds in other settings, this suggests that regulation or changes in tax policy designed to curtail debt bias will have little effect on corporate debt usage and solvency. 


\section{References}

Andrade, G. and S. Kaplan, 1998, "How Costly is Financial (not Economic) Distress? Evidence from Highly Levered Transactions that Became Distressed," Journal of Finance 53, 1443-1493.

Berger, P. G., E. Ofek, and D. Yermack, 1997, "Managerial Entrenchment and Capital Structure Decisions," Journal of Finance 52, 1411-1438.

Bernanke, B., 1983, "Nonmonetary Effects of the Financial Crisis in Propagation of the Great Depression," American Economic Review 73, 257-76.

Bernanke, B., 1995, "The Macroeconomics of the Great Depression: A Comparative Approach," Journal of Money, Credit and Banking 27, 1-28.

Bernstein, M. A, 1987, The Great Depression, Cambridge: Cambridge University Press.

Bresnehan, T. and D. Raff, 1991, "American Motor Vehicles Industry, 1929-1935," Journal of Economic History 51, 317-332.

Bresnehan, T. and D. Raff, 1992, "Technological Heterogeneity, Adjustment Costs, and the Dynamics of Plant Shut-Down Behavior: The American Motor Vehicle Industry in the Time of the Great Depression," Harvard Business School, Working Paper \#92-097 (June 1992).

Bris, A., I. Welch, and N. Zhu, 2006, "The Costs of Bankruptcy: Chapter 7 Liquidation versus Chapter 11 Reorganization," Journal of Finance 61, 1253-1303.

Burch, T. R., W. G. Christie and V. Nanda, 2004, "Do Firm's Time Equity Offerings? Evidence from the 1930s and 1940s," Financial Management 33, 5-23.

Calomiris, C. W., and R. G. Hubbard, 1995, "Internal Finance and Investment: Evidence from the Undistributed Profits Tax of 1936-1937," Journal of Business 68, 443-482.

Campello, M., and Z. Fluck, 2006, "Market Share, Financial Leverage, and the Macroeconomy: Theory and Empirical Evidence," University of Illinois Working Paper.

Chevalier, J., and D. Scharfstein, 1996, "Capital-Market Imperfections and CounterCyclical Markups: Theory and Evidence," American Economic Review 86, 703-725.

Christie, W. G. and V. Nanda, 1994, "Free Cash Flow, Shareholder Value, and the Undistributed Profits Tax of 1936 and 1937," Journal of Finance 49, 1727-1754

Ely, K. and G. Waymire, 1999, "Intangible Assets and Stock Prices During the Pre-Sec Era," Journal of Accounting Research 37, 17-44.

Fama, E. F. and K. R. French, 1997, "Industry Costs of Equity," Journal of Financial Economics 43, 153-193 
Fisher, I., 1933, "The Debt-Deflation Theory of Great Depressions," Econometrica 1, 337-57.

Gordon, R. A., 1936, "Stockholdings of Officers and Directors in American Industrial Corporations," Quarterly Journal of Economics 50, 622-657.

Gordon, R. A., 1938, "Ownership by Management and Control Groups in Large Corporations," Quarterly Journal of Economics 52, 367-400.

Graham, J. R., 2000, "How Big are the Tax Benefits of Debt?," Journal of Finance 55, 1901-1941.

Graham, J. R., 2003, "Taxes and Corporate Finance: A Review," Review of Financial Studies 16, 1075-1129.

Graham, J.R., S. Hazarika, and K. Narasimhan, 2012, "Corporate Governance, Debt, and Investment Policy during the Great Depression," Management Science forthcoming.

Hadlock, C. J. and G. B. Lumer, 1997, "Compensation, Turnover, and Top Management Incentives: Historical Evidence," Journal of Business 70, 153-187.

Holderness, C. G., R. S. Kroszner, and D. P. Sheehan, "Were The Good Old Days That Good? Changes in Managerial Stock Ownership since the Great Depression," Journal of Finance 54, 435-469.

Hunter, H. M., 1982, "The Role of Business Liquidity during the Great Depression and Afterwards: Differences Between Large and Small Firms," Journal of Economic History 42, 883-902.

IMF, 2011, "Tax Biases to Debt Finance: Assessing the Problem, Finding Solutions."

Jensen, M., 1986, "Agency Cost of Free Cash Flow, Corporate Finance, and Free Cash Flows," American Economic Review 76, 323-329.

Jovanovic, B. and P. L. Rousseau, 2000, "Technology and the Stock Market: 1885 1998," Vanderbilt University Working Paper.

Myers, S. C, 1977, "Determinants of Corporate Borrowing," Journal of Financial Economics 5, 147-175.

Opler, T. C., and S. Titman, 1994, "Financial Distress and Corporate Performance," Journal of Finance 59, 1015-1040.

Safieddine, A. and S. Titman, 1999, "Leverage and Corporate Performance: Evidence from Unsuccessful Takeovers," Journal of Finance 54, 547-580.

Schiffman, D., 2003, "Shattered Rails, Ruined Credit: Financial Fragility and Railroad Operations in the Great Depression," The Journal of Economic History 63, 802-.825. 
Scott, J. H., Jr, 1976, "A Theory of Optimal Capital Structure," Bell Journal of Economics 7, 33-54.

Shumway, T., 2001, "Forecasting Bankruptcy More Accurately: A Simple Hazard Model," Journal of Business 74, 101-124.

Stinchcombe, A. L., 1965, "Social Structures and Organizations," J. G. March (Ed.) Handbook of Organizations, Rand McNally \& Company, 142-193.

Taussig, F. W. and W. S. Baker, 1925, "American Corporations and Their Executives: A Statistical Inquiry," Quarterly Journal of Economics 40, 1-51.

van Binsbergen, J., J. R. Graham, and J. Yang, 2010, "The Cost of Debt," Journal of Finance 65, 2089-2136.

Warner, J. B., 1977, "Bankruptcy Costs: Some Evidence," Journal of Finance 32, 337347.

Weiss, L., 1990, “Bankruptcy Resolution,” Journal of Financial Economics 27, 285-314.

Zingales, L., 1998, "Survival of the Fittest or Fattest? Exit and Financing in the Trucking Industry," Journal of Finance 53, 905-938. 


\section{Figure 1: Impact on Corporate Sector}

Panel A shows the total corporate borrowing from 1928 to 1938. Panel B shows the funds raised through new stock issues from 1928 to 1938. Panel C shows the index of manufacturing production, and Panel D shows the number of business failures from 1920 to 1938 (source: Statistical Abstract of the United States).

Panel A

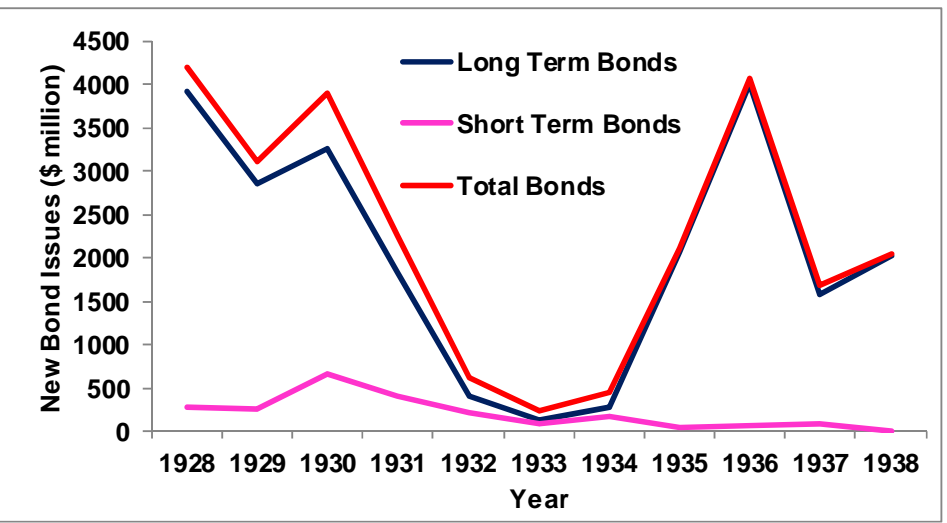

Panel C

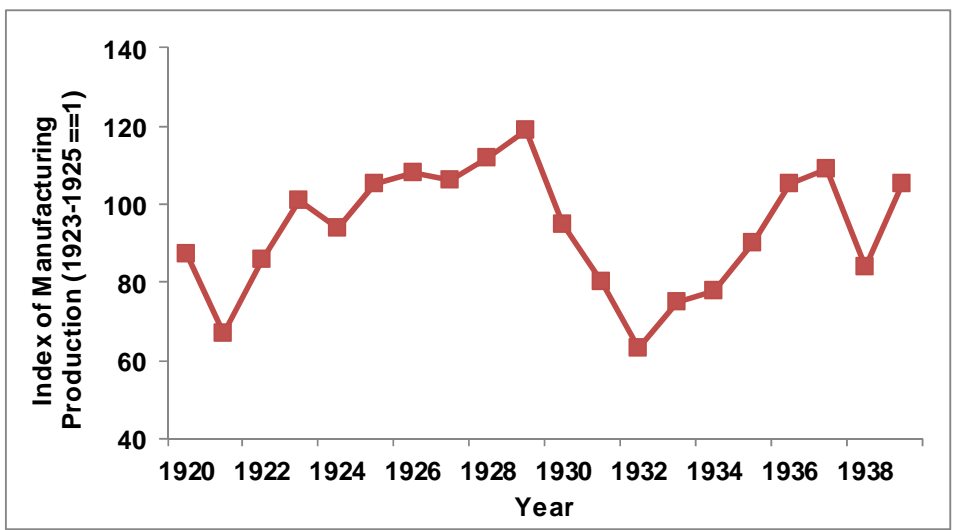

Panel B

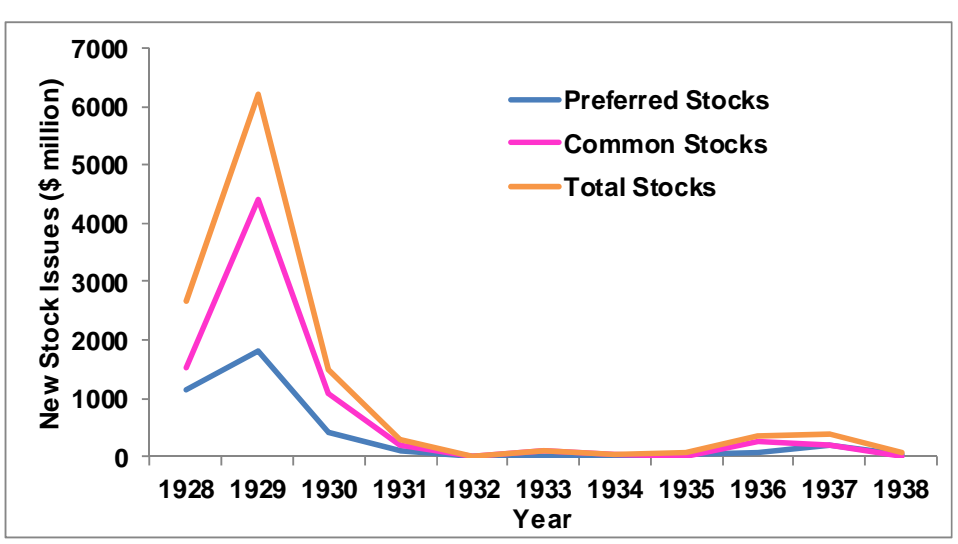

Panel D

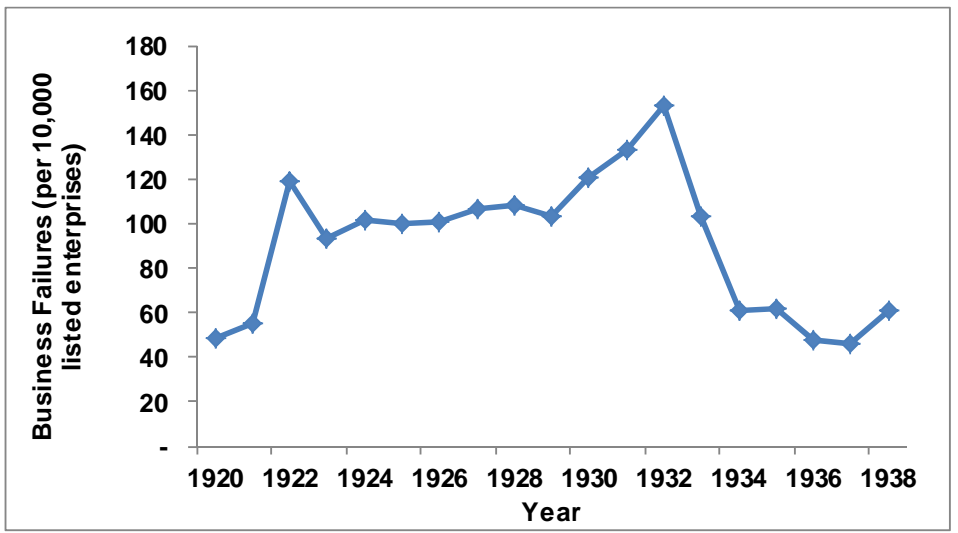




\section{Figure 2: Income, Distribution, and Distress}

Panel A shows the percentage of firms with positive net income from 1928 to 1936. Panel B shows a decline in dividend per share from 1929 to 1938 (source: Statistical Abstract of the United States).

Panel $C$ is based on 463 industrial companies on CRSP during 1926-1938. It shows the cumulative percentage of firms that became distressed in the sample, where distress is defined as liquidation, filing for bankruptcy, undertaking a court ordered reorganization, undertaking a recapitalization when the stock is listed as worthless, or being explicitly listed as being financially distressed.

Panel A

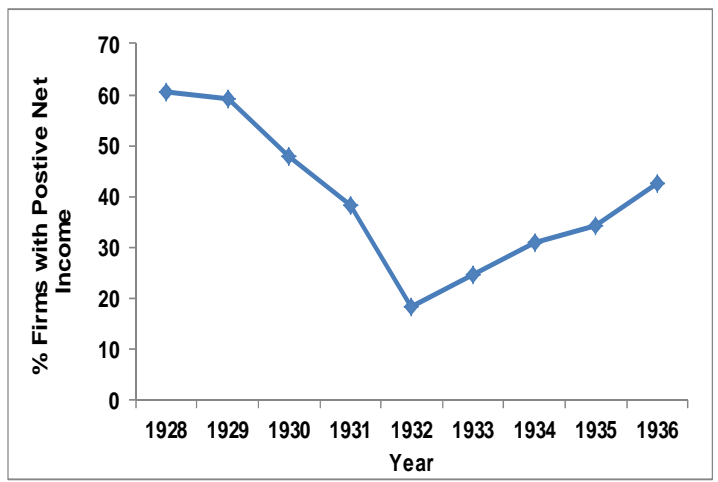

Panel B

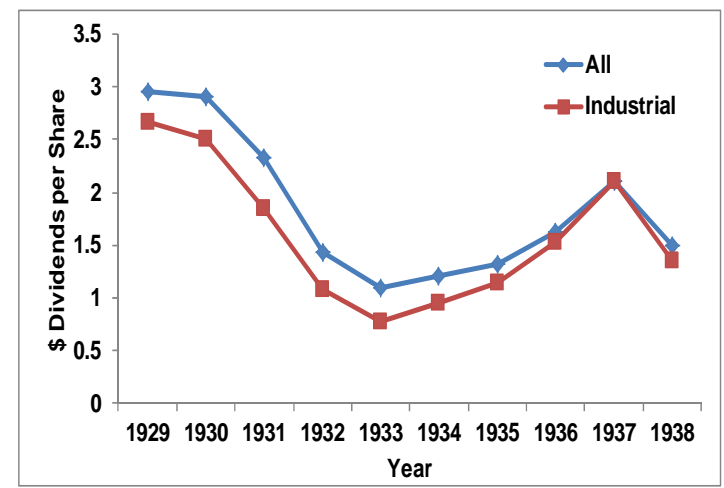

Panel C

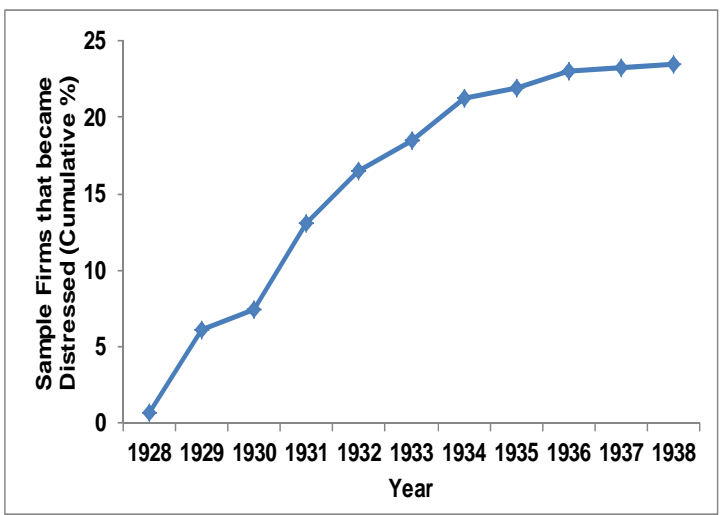




\section{Figure 3: Impact of Debt on Market Valuation}

This figure shows the change in Tobin's q of the highest and lowest leverage quartiles, crossed with all four market to book quartiles. Each sort is unconditional. The impact of leverage was largest in 'value firms' (low market to book) and smallest in 'growth' firms (high market to book).

Low MB

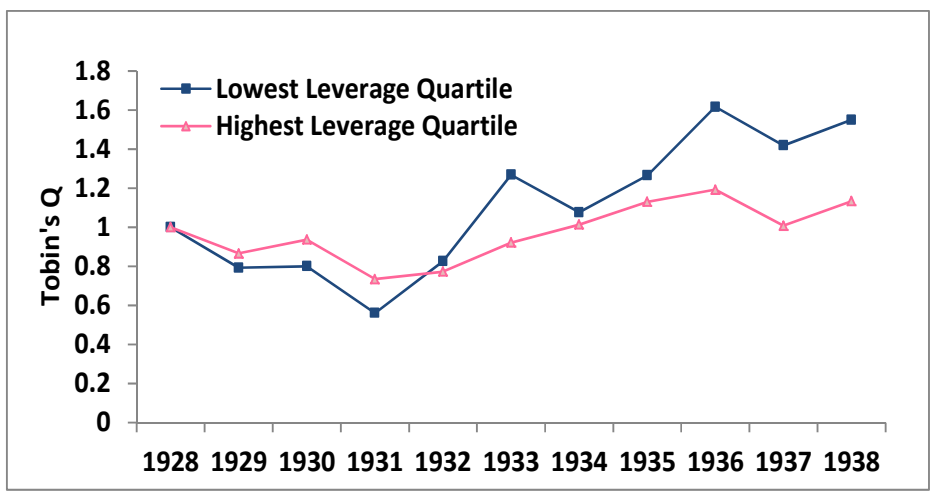

Mid-High MB

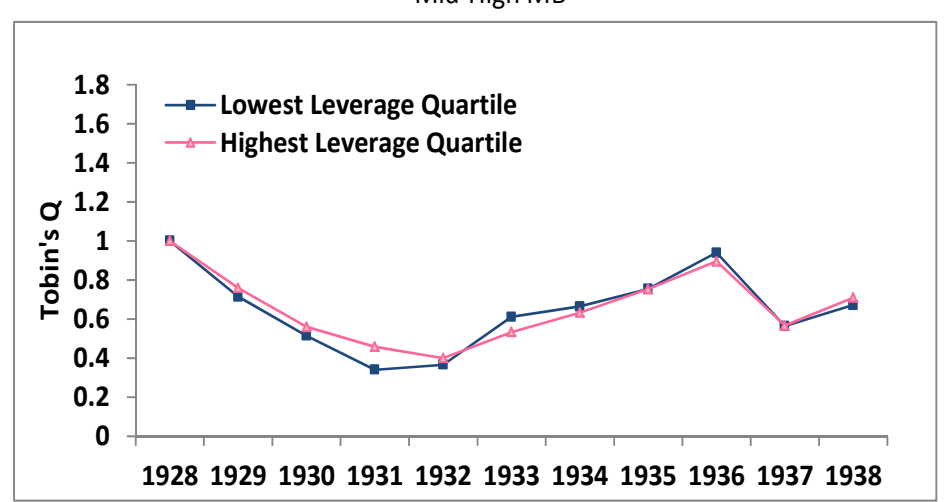

Low-Mid MB

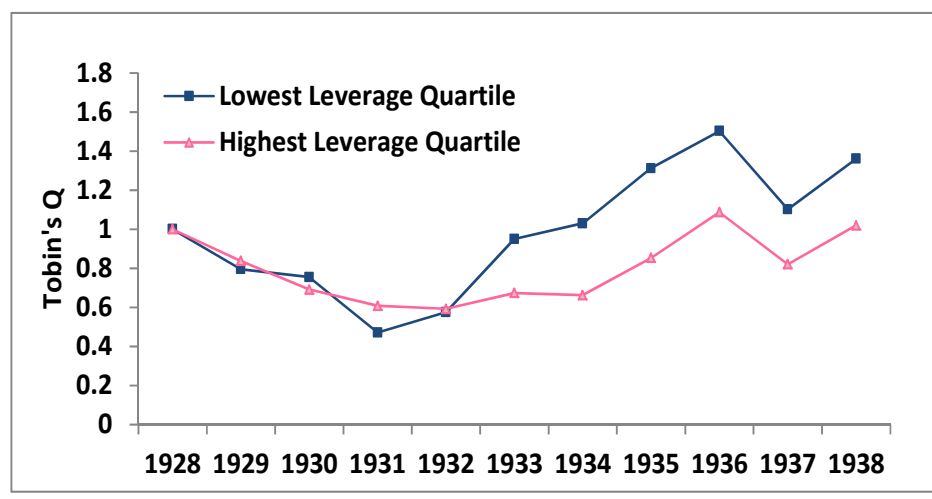

High MB

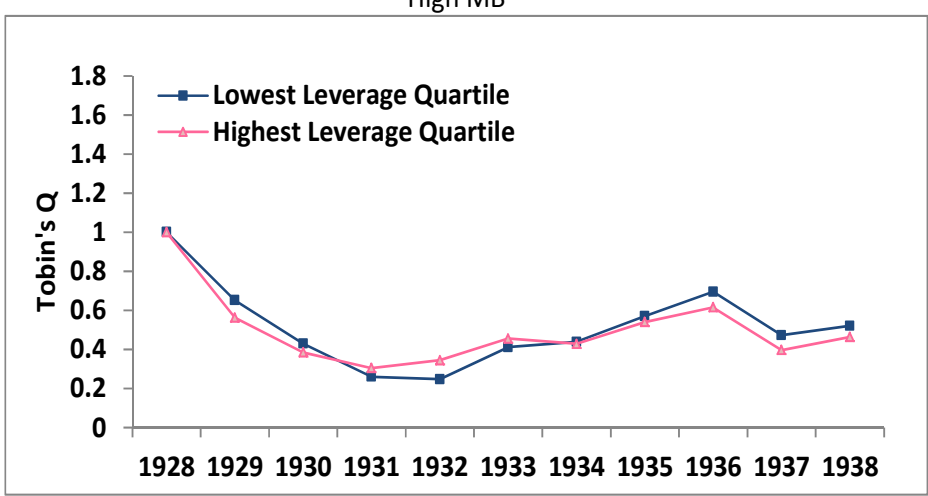




\section{Table I: Summary Statistics for 1928}

Panel A gives summary statistics for 1928. M/B is the market equity divided by book equity. Return and Volatility are measured as the firm's stock return and volatility during 1928. Operating profit is earnings before interest and tax (EBIT) divided by total assets. Size is the ratio of the market capitalization of the firm to the total market capitalization of all the firms listed on CRSP. Leverage is the ratio of total debt to total assets. Ratings ranges from 1 to 9 , with 9 representing AAA and 1 representing $C$. Investment during the year is calculated as the difference in gross fixed assets between the beginning and the end of the year, divided by beginning of the year total assets. Current assets are measured as the ratio of current assets to total assets. Age is the number of years the firm has been in existence. Panel B reports the pair-wise correlations among the explanatory variables.

Panel A: Summary Statistics

\begin{tabular}{lrrrrr}
\hline \hline Variable & Mean & Median & Std. Dev. & $25^{\text {th }}$ percentile & $75^{\text {th }}$ percentile \\
\hline M/B & 1.40 & 0.78 & 2.97 & 0.49 & 1.36 \\
Return & 0.36 & 0.17 & 0.94 & -0.06 & 0.56 \\
Volatility & 10.30 & 5.68 & 14.03 & 2.77 & 11.27 \\
Operating Profit & 0.09 & 0.08 & 0.11 & 0.04 & 0.12 \\
Size(percent) & 0.15 & 0.03 & 0.41 & 0.01 & 0.10 \\
Leverage & 0.12 & 0.07 & 0.14 & 0.00 & 0.18 \\
Rating & 5.84 & 6.00 & 1.50 & 5.00 & 7.00 \\
Investment & 0.03 & 0.00 & 0.22 & -0.01 & 0.03 \\
Current Assets & 0.35 & 0.32 & 0.20 & 0.18 & 0.49 \\
Age & 22.58 & 18.50 & 16.65 & 11.00 & 29.00 \\
\hline \hline
\end{tabular}


Panel B: Correlation Matrix

\begin{tabular}{|c|c|c|c|c|c|c|c|c|c|c|}
\hline & $\mathrm{M} / \mathrm{B}$ & Return & Volatility & $\begin{array}{l}\text { Operating } \\
\text { Profit } \\
\end{array}$ & Log(Size) & Leverage & $\begin{array}{l}\text { Log(Rating } \\
\text { ) }\end{array}$ & Investment & Current Assets & Age \\
\hline $\mathrm{M} / \mathrm{B}$ & 1.00 & & & & & & & & & \\
\hline Return & -0.02 & 1.00 & & & & & & & & \\
\hline Operating Profit & $-0.16^{\star * *}$ & 0.02 & $0.26^{\star \star \star}$ & 1.00 & & & & & & \\
\hline Log(Size) & $-0.29 * \star \star$ & 0.07 & $0.43^{\star \star \star}$ & $0.35^{\star \star \star}$ & 1.00 & & & & & \\
\hline Leverage & $0.09^{*}$ & 0.04 & $-0.12^{\star \star}$ & $-0.22^{\star \star *}$ & $-0.21^{\star * *}$ & 1.00 & & & & \\
\hline Current Assets & $-0.20^{\star \star *}$ & -0.03 & 0.08 & $0.21^{\star \star *}$ & -0.01 & $-0.11^{\star *}$ & 0.07 & -0.04 & 1.00 & \\
\hline Age & -0.04 & -0.01 & 0.07 & -0.06 & 0.05 & $-0.08^{*}$ & $0.13^{\star \star \star}$ & $-0.09 *$ & $0.11^{* *}$ & 1.00 \\
\hline
\end{tabular}


Table II: Summary Statistics, by Year and Entire Panel

The table contains summary statistics for key years and for the entire sample. Operating profit is calculated as earnings before interest and tax (EBIT) divided by the total assets of the firm. Leverage is calculated as the ratio of total debt to total assets.

\begin{tabular}{|c|c|c|c|c|c|c|}
\hline Variable & Year & Mean & Median & Std. Dev. & Max & Min \\
\hline Operating Profit & 1928 & 0.09 & 0.08 & 0.11 & 1.33 & -0.30 \\
\hline Leverage & 1928 & 0.12 & 0.07 & 0.14 & 0.74 & 0.00 \\
\hline Fixed Assets (\$ million) & 1928 & 35.58 & 10.59 & 103.00 & 1661.12 & 0.00 \\
\hline Total Assets (\$ million) & 1928 & 70.80 & 24.40 & 174.83 & 2442.03 & 0.40 \\
\hline Operating Profit & 1932 & -0.01 & -0.01 & 0.10 & 0.53 & -0.86 \\
\hline Leverage & 1932 & 0.10 & 0.02 & 0.14 & 0.80 & 0.00 \\
\hline Fixed Assets (\$ million) & 1932 & 40.71 & 9.94 & 128.37 & 1650.82 & 0.00 \\
\hline Total Assets (\$ million) & 1932 & 74.37 & 20.92 & 198.36 & 2158.73 & 0.93 \\
\hline Operating Profit & 1933 & 0.03 & 0.02 & 0.07 & 0.34 & -0.33 \\
\hline Leverage & 1933 & 0.10 & 0.01 & 0.14 & 0.74 & 0.00 \\
\hline Fixed Assets (\$ million) & 1933 & 41.53 & 9.08 & 128.76 & 1653.92 & 0.00 \\
\hline Total Assets ( $\$$ million) & 1933 & 76.91 & 20.28 & 202.92 & 2102.90 & 0.85 \\
\hline Operating Profit & 1938 & 0.05 & 0.04 & 0.11 & 1.30 & -0.28 \\
\hline Leverage & 1938 & 0.08 & 0.01 & 0.12 & 0.77 & 0.00 \\
\hline Fixed Assets (\$ million) & 1938 & 43.37 & 9.79 & 121.31 & 1172.25 & 0.04 \\
\hline Total Assets ( $\$$ million) & 1938 & 83.20 & 21.87 & 207.04 & 2044.64 & 0.64 \\
\hline Operating Profit & 1926 to 1938 & 0.06 & 0.05 & 0.10 & 1.34 & -0.86 \\
\hline Leverage & 1926 to 1938 & 0.10 & 0.04 & 0.14 & 0.99 & 0.00 \\
\hline Fixed Assets (\$ million) & 1926 to 1938 & 40.37 & 10.21 & 118.04 & 1709.78 & 0.00 \\
\hline Total Assets (\$ million) & 1926 to 1938 & 77.49 & 23.86 & 195.39 & 2454.14 & 0.40 \\
\hline
\end{tabular}




\section{Table III: Logistic Regression of Distress during the Depression on Explanatory Variables Measured in 1928}

The table provides the parameter estimates of the logistic regression of Distress on 1928 firm characteristics. We use a binary variable, Distress, as the dependent variable in our logistic regression; the variable takes the value 1 if the firm liquidated, filed for bankruptcy, undertook a court ordered reorganization because of bankruptcy filings, undertook a recapitalization when its stock became worthless, or was explicitly listed as being financially distressed during the Depression and 0 otherwise. In Panel A, the Distress variable is measured over 1930-1938, while in Panel B the Distress variable is measured over 1930-1933. M/B is the market equity divided by book equity. Return and Volatility are measured as the firm's stock return and volatility during 1928. Operating profit is earnings before interest and tax (EBIT) divided by total assets. Size is the ratio of the market capitalization of the firm to the total market capitalization of all the firms listed on CRSP. Leverage is the ratio of total debt to total assets. Ratings ranges from 1 to 9, with 9 representing AAA and 1 representing $C$. Investment during the year is calculated as the difference in gross fixed assets between the beginning and the end of the year, divided by beginning of the year total assets. Current assets are measured as the ratio of current assets to total assets. Age is the number of years the firm has been in existence. The Durable Goods indicator variable has a value of 1 if a firm is assigned a 1-digit SIC code of 1,3, or 4. Two-sided p-values, using robust standard errors, are in parentheses beneath the coefficient estimates.

Panel A: Logistic Regression of Distress during 1930-1938 on Explanatory Variables Measured in 1928

\begin{tabular}{lccccc}
\hline Distress & $(1)$ & $(2)$ & $(3)$ & $(4)$ & $(5)$ \\
\hline M/B & -0.105 & -0.222 & -0.266 & -0.286 & -0.268 \\
& $(0.47)$ & $(0.23)$ & $(0.11)$ & $(0.09)$ & $(0.11)$ \\
Return & 0.136 & -0.020 & 0.003 & 0.014 & -0.007 \\
Volatility & $(0.67)$ & $(0.95)$ & $(0.99)$ & $(0.96)$ & $(0.98)$ \\
& -0.040 & -0.019 & -0.023 & -0.022 & -0.024 \\
Operating Profit & $(0.19)$ & $(0.47)$ & $(0.42)$ & $(0.45)$ & $(0.41)$ \\
& -4.156 & -1.420 & 0.063 & -0.082 & 0.148 \\
Log(Size) & $(0.16)$ & $(0.64)$ & $(0.98)$ & $(0.98)$ & $(0.96)$ \\
& & & & & \\
Leverage & -0.321 & -0.100 & -0.070 & -0.077 & -0.062 \\
& $(0.00)$ & $(0.44)$ & $(0.61)$ & $(0.57)$ & $(0.65)$ \\
Log(Rating) & 4.733 & & 4.683 & 4.603 & 4.816 \\
& $(0.00)$ & & $(0.00)$ & $(0.00)$ & $(0.00)$ \\
Investment & & -3.305 & -3.278 & -3.163 & -3.308 \\
& & $(0.00)$ & $(0.00)$ & $(0.00)$ & $(0.00)$ \\
Current Assets & 1.823 & 1.657 & 1.883 & 1.750 & 2.001 \\
Log(Age) & $(0.23)$ & $(0.28)$ & $(0.25)$ & $(0.29)$ & $(0.22)$ \\
Durable Goods & -0.360 & -0.320 & -0.221 & -0.121 & -0.194 \\
-Log Likelihood & $(0.61)$ & $(0.66)$ & $(0.77)$ & $(0.87)$ & $(0.80)$ \\
Number of Observations & 408 & 408 & 408 & 408 & 408 \\
\hline \hline
\end{tabular}


Panel B: Logistic Regression of Distress during 1930-1933 on Explanatory Variables Measured in 1928

\begin{tabular}{llllll}
\hline \hline Distress & $(1)$ & $(2)$ & $(3)$ & $(4)$ & $(5)$ \\
\hline M/B & -0.055 & -0.168 & -0.206 & -0.231 & -0.205 \\
& $(0.74)$ & $(0.41)$ & $(0.27)$ & $(0.22)$ & $(0.27)$ \\
Return & -0.019 & -0.155 & -0.134 & -0.119 & -0.131 \\
Volatility & $(0.96)$ & $(0.62)$ & $(0.69)$ & $(0.72)$ & $(0.70)$ \\
& -0.013 & 0.005 & 0.004 & 0.005 & 0.004 \\
Operating Profit & $(0.64)$ & $(0.84)$ & $(0.88)$ & $(0.84)$ & $(0.87)$ \\
& -7.220 & -3.839 & -2.728 & -2.959 & -2.787 \\
Log(Size) & $(0.03)$ & $(0.24)$ & $(0.41)$ & $(0.38)$ & $(0.41)$ \\
& -0.315 & -0.093 & -0.067 & -0.078 & -0.070 \\
Leverage & $(0.01)$ & $(0.50)$ & $(0.64)$ & $(0.59)$ & $(0.63)$ \\
& 4.444 & & 4.333 & 4.225 & 4.277 \\
Log(Rating) & $(0.00)$ & & $(0.00)$ & $(0.00)$ & $(0.00)$ \\
& & -3.441 & -3.372 & -3.216 & -3.359 \\
Investment & & $(0.00)$ & $(0.00)$ & $(0.00)$ & $(0.00)$ \\
& & 1.970 & 2.093 & 1.929 & 2.045 \\
Current Assets & $(0.141$ & $(0.23)$ & $(0.22)$ & $(0.26)$ & $(0.23)$ \\
& -0.332 & -0.336 & -0.229 & -0.102 & -0.241 \\
Ln(Age) & $(0.66)$ & $(0.67)$ & $(0.77)$ & $(0.90)$ & $(0.76)$ \\
Durable Goods & & & & -0.234 & \\
Number of Observations & 408 & 408 & 408 & 408 & 408 \\
\hline \hline
\end{tabular}




\section{Table IV: Debt Bias Analysis}

In the first stage regression, debt usage in 1928 is the dependent variable. The fitted value from the first stage regression is used as the instrument for leverage in the second stage regressions. In the second stage logistic regression, a binary variable Distress, is the dependent variable; the variable takes the value 1 if the firm liquidated, filed for bankruptcy, undertook a court ordered reorganization because of bankruptcy filings, undertook a recapitalization when its stock became worthless, or was explicitly listed as being financially distressed during the Depression (1930-1938) and 0 otherwise. MTR is a dummy variable equal to 1 if a firm had positive tax liabilities in 1927, i.e. the firm had taxable income greater than $\$ 2000$ in 1927 , and 0 otherwise. Tangibility is the ratio of fixed assets to total assets. Two-sided p-values, using robust standard errors, are in parentheses beneath the coefficient estimates.

\begin{tabular}{|c|c|c|c|c|c|}
\hline \multirow[t]{2}{*}{ Variable } & \multirow[t]{2}{*}{$\begin{array}{l}\text { Debt Usage } \\
\text { (first stage) }\end{array}$} & \multicolumn{4}{|c|}{$\begin{array}{c}\text { Distress } \\
\text { (second stage) }\end{array}$} \\
\hline & & (1) & (2) & (3) & (4) \\
\hline MTR & $\begin{array}{l}0.037 \\
(0.06)\end{array}$ & & & & \\
\hline Tangibility & $\begin{array}{l}-0.005 \\
(0.86)\end{array}$ & & & & \\
\hline M/B & $\begin{array}{l}0.008 \\
(0.38)\end{array}$ & $\begin{array}{l}0.058 \\
(0.22)\end{array}$ & $\begin{array}{l}0.032 \\
(0.42)\end{array}$ & $\begin{array}{l}0.026 \\
(0.53)\end{array}$ & $\begin{array}{l}0.032 \\
(0.43)\end{array}$ \\
\hline Return & & $\begin{array}{c}-0.024 \\
(0.84)\end{array}$ & $\begin{array}{l}-0.121 \\
(0.38)\end{array}$ & $\begin{array}{l}-0.104 \\
(0.42)\end{array}$ & $\begin{array}{l}-0.121 \\
(0.37)\end{array}$ \\
\hline Volatility & & $\begin{array}{c}-0.043 \\
(0.11)\end{array}$ & $\begin{array}{c}-0.032 \\
(0.16)\end{array}$ & $\begin{array}{l}-0.031 \\
(0.18)\end{array}$ & $\begin{array}{l}-0.031 \\
(0.17)\end{array}$ \\
\hline Operating Profit & $\begin{array}{l}-0.008 \\
(0.95)\end{array}$ & $\begin{array}{l}-3.662 \\
(0.11)\end{array}$ & $\begin{array}{l}-1.582 \\
(0.40)\end{array}$ & $\begin{array}{l}-1.786 \\
(0.35)\end{array}$ & $\begin{array}{l}-1.578 \\
(0.40)\end{array}$ \\
\hline Log(Size) & $\begin{array}{l}-0.001 \\
(0.78)\end{array}$ & $\begin{array}{l}-0.373 \\
(0.00)\end{array}$ & $\begin{array}{l}-0.163 \\
(0.19)\end{array}$ & $\begin{array}{l}-0.172 \\
(0.17)\end{array}$ & $\begin{array}{l}-0.163 \\
(0.19)\end{array}$ \\
\hline Leverage Fitted Value & & $\begin{array}{r}-7.551 \\
(0.39)\end{array}$ & $\begin{array}{l}-5.869 \\
(0.50)\end{array}$ & $\begin{array}{l}-5.813 \\
(0.51)\end{array}$ & $\begin{array}{l}-6.014 \\
(0.50)\end{array}$ \\
\hline Log(Rating) & & & $\begin{array}{l}-2.433 \\
(0.00)\end{array}$ & $\begin{array}{l}-2.314 \\
(0.00)\end{array}$ & $\begin{array}{r}-2.432 \\
(0.00)\end{array}$ \\
\hline Investment & & $\begin{array}{l}1.368 \\
(0.01)\end{array}$ & $\begin{array}{l}1.314 \\
(0.02)\end{array}$ & $\begin{array}{l}1.237 \\
(0.02)\end{array}$ & $\begin{array}{l}1.307 \\
(0.02)\end{array}$ \\
\hline Current Assets & $\begin{array}{l}-0.024 \\
(0.49)\end{array}$ & $\begin{array}{l}-0.704 \\
(0.29)\end{array}$ & $\begin{array}{l}-0.625 \\
(0.37)\end{array}$ & $\begin{array}{l}-0.497 \\
(0.48)\end{array}$ & $\begin{array}{l}-0.632 \\
(0.37)\end{array}$ \\
\hline $\log ($ Age $)$ & & & & $\begin{array}{l}-0.236 \\
(0.14)\end{array}$ & \\
\hline Durable Goods & & & & & $\begin{array}{l}-0.036 \\
(0.90)\end{array}$ \\
\hline $\begin{array}{l}\mathrm{R}^{2} \text { /-Log Likelihood } \\
\text { Number of } \\
\text { Observations }\end{array}$ & $\begin{array}{l}0.02 \\
407\end{array}$ & $\begin{array}{c}-182.50 \\
407\end{array}$ & $\begin{array}{c}-175.89 \\
407\end{array}$ & $\begin{array}{c}-174.84 \\
407\end{array}$ & $\begin{array}{c}-175.88 \\
407\end{array}$ \\
\hline
\end{tabular}




\section{Table V: Logistic Regression of Distress during the 2008-2009 Recession on Explanatory Variables Measured in 2006}

The table provides the parameter estimates of the logistic regression of Distress on 2006 firm characteristics. We use a binary variable, Distress, as the dependent variable in our logistic regression; the variable takes the value 1 if the firm filed for bankruptcy during 2008-June 2011 and 0 otherwise. The sample includes firms with $\$ 100$ million or more of total assets (measured in 1980 dollars). $M / B$ is the market equity divided by book equity. Return and Volatility are measured as the firm's stock return and volatility during 2006. Operating profit is earnings before interest and tax (EBIT) divided by total assets. Size is the ratio of the market capitalization of the firm to the total market capitalization of all the firms listed on CRSP. Leverage is the ratio of total debt to total assets. Ratings ranges from 1 to 10, with 10 representing AAA and 1 representing D. Investment during the year is calculated as net investments during the year, divided by beginning of the year total assets. Current assets are measured as the ratio of current assets to total assets. . Two-sided p-values, using robust standard errors, are in parentheses beneath the coefficient estimates.

\begin{tabular}{|c|c|c|c|}
\hline Distress & $(1)$ & $(2)$ & (3) \\
\hline$M / B$ & $\begin{array}{l}-0.067 \\
(0.62)\end{array}$ & $\begin{array}{l}-0.114 \\
(0.56)\end{array}$ & $\begin{array}{l}-0.159 \\
(0.38)\end{array}$ \\
\hline Return & $\begin{array}{l}-2.725 \\
(0.00)\end{array}$ & $\begin{array}{l}-3.097 \\
(0.00)\end{array}$ & $\begin{array}{l}-3.110 \\
(0.00)\end{array}$ \\
\hline Volatility & $\begin{array}{l}-0.048 \\
(0.62)\end{array}$ & $\begin{array}{l}0.043 \\
(0.67)\end{array}$ & $\begin{array}{l}0.065 \\
(0.53)\end{array}$ \\
\hline Operating Profit & $\begin{array}{l}-6.192 \\
(0.05)\end{array}$ & $\begin{array}{l}-3.661 \\
(0.43)\end{array}$ & $\begin{array}{l}-4.290 \\
(0.29)\end{array}$ \\
\hline Log(Size) & $\begin{array}{l}-0.597 \\
(0.00)\end{array}$ & $\begin{array}{l}-0.347 \\
(0.22)\end{array}$ & $\begin{array}{l}-0.282 \\
(0.29)\end{array}$ \\
\hline Leverage & $\begin{array}{l}2.345 \\
(0.00)\end{array}$ & & $\begin{array}{l}2.638 \\
(0.06)\end{array}$ \\
\hline Log(Rating) & & $\begin{array}{l}-6.486 \\
(0.00)\end{array}$ & $\begin{array}{l}-5.356 \\
(0.03)\end{array}$ \\
\hline Investment & $\begin{array}{l}-1.649 \\
(0.57)\end{array}$ & $\begin{array}{l}-6.724 \\
(0.18)\end{array}$ & $\begin{array}{l}-6.927 \\
(0.19)\end{array}$ \\
\hline Current Assets & $\begin{array}{l}0.205 \\
(0.78)\end{array}$ & $\begin{array}{l}0.377 \\
(0.70)\end{array}$ & $\begin{array}{l}1.290 \\
(0.22)\end{array}$ \\
\hline $\begin{array}{l}\text {-Log Likelihood } \\
\text { Number of Observations }\end{array}$ & $\begin{array}{l}-177.72 \\
2075\end{array}$ & $\begin{array}{l}-85.11 \\
1012\end{array}$ & $\begin{array}{l}-83.46 \\
999\end{array}$ \\
\hline
\end{tabular}




\section{Table VI: Value Loss, Conditional on Growth Options and Leverage}

The percentage changes in market valuation (Tobin's q) between the portfolios containing firms in the highest and the lowest leverage quartiles during the year are shown. Column (1) presents the result for the lowest market-to-book quartile. Column (2) presents the result for the second quartile, Column (3) for the third quartile, and Column (4) presents the result for the highest market-to-book quartile.

Consequence of Leverage on Firm Value during the Depression
(1)

Low M/B (value)

$-0.2074-0.1345$

\section{8-1929}

1928-1930

1928-1931

1928-1932

1928-1933

1928-1934

1928-1935

1928-1936

1928-1937

1928-1938

$-0.0633$

$-0.2654$

$-0.2274$

$-0.0785$

0.0134

0.1298

0.1921

0.0078

0.1333

\section{$-0.2074$}

$-0.2001$

$-0.4389$

$-0.1746$

0.2684

0.0758

0.2649

0.6161

0.4191

0.5497
$-0.0729$

$-0.1368$

$-0.1735$

0.0528

0.3469 **

0.0624

0.1351

$0.4241^{\text {** }}$

$0.4113^{\star *}$

$0.4164^{*}$

** Significant at the $0.05 \%$ level.

* Significant at the $0.10 \%$ level.
(3)

Mid-High M/B

Low Debt High Debt

$-0.2049$

$-0.2452$

$-0.5294$

$-0.4247$

$-0.0501$

0.0297

0.3123

0.5024

0.1015

0.3602
(2)

High Debt Low-High

$-0.1627$

$-0.3084$

$-0.3918$

$-0.4077$

$-0.3267$

$-0.3375$

$-0.1466$

0.0874

$-0.1792$

0.0198
$-0.0422$

0.0632

$-0.1376$

$-0.0169$

0.2766

$0.3672^{*}$

$0.4588^{*}$

0.4151 *

0.2806

0.3404
$-0.2860$

$-0.4854$

$-0.6593$

$-0.6342$

$-0.3885$

$-0.3360$

$-0.2460$

$-0.0602$

$-0.4363$

$-0.3289$
$-0.2405$

$-0.4938$

$-0.5420$

$-0.6002$

$-0.4666$

$-0.3671$

$-0.2468$

$-0.1046$

$-0.4333$

$-0.2902$

$$
\text { quartile. }
$$

